\title{
MULTI-CRITERIA COMPARATIVE ANALYSIS OF WATER-SUPPLY AND SEWERAGE PIPES MANUFACTURED FROM DIFFERENT MATERIALS
}

\begin{abstract}
Vincas GURSKIS, Department of Water Engineering, Faculty of Engineering, Vytautas Magnus University, K. Donelaičio g. 58, 44248 Kaunas Lithuania, vincas.gurskis@vdu.lt (corresponding author)

Rytis SKOMINAS, Department of Water Engineering, Faculty of Engineering, Vytautas Magnus University, K. Donelaičio g. 58, 44248 Kaunas Lithuania, rytis.skominas@vdu.lt

Raimondas ŠADZEVIČIIUS, Department of Water Engineering, Faculty of Engineering, Vytautas Magnus University, K. Donelaičio g. 58, 44248 Kaunas Lithuania, raimondas.sadzevicius@ @du.lt

Recent advances in materials engineering are remarkable. New materials are emerging in the global market, and old ones are constantly being improved. No exceptions and materials for the production of pipes. Nowadays cast iron, steel, reinforced concrete, ceramic, plastic and other materials pipes are used for water supply and sewage networks installation. Construction customers and designers have to choose which materials to use for pipes that they meet the set requirements, are easy to maintain, and to have high longevity. To evaluate the effectiveness of different pipe materials (concrete, reinforced concrete (RC), steel, cast iron, ceramic, polyvinylchloride $(\mathrm{PVC})$, polyethylene (PE), polypropylene (PP), glass reinforced plastic (GRP)), the properties and cost were analyzed. Eleven criteria were selected for the evaluation: variety of diameters, mass, resistance of lifting, thermal resistance, abrasion resistance, surface roughness (hydraulic property), nominal stiffness, nominal pressure, embodied energy, $\mathrm{CO}_{2}$ emission, and cost (product + installation). According to the results the most effective material for pipes used in water supply and sewerage systems is polyethylene PE and polyvinylchloride PVC.
\end{abstract}

Keywords: pipe, material, cost, efficiency.

\section{INTRODUCTION}

Intensive reconstruction and development of water supply and sewerage networks is currently underway. The technology for transporting water by pipelines remains the same. Only the materials used to install the pipeline are constantly changing and evolving. Efforts are always made to produce durable and easy-to-install piping systems. Sometimes very unusual circumstances have to be overcome, such as high pressure and temperature or when transporting aggressive liquids. Cast iron, steel, reinforced concrete, ceramic, plastic and other materials pipes are used for water supply and sewage networks installation.

Construction customers and designers have to choose which materials to use for pipes that they meet the set requirements, are easy to maintain, and to have high longevity.

As specified in Construction Law, all structures, including water supply and sewage networks, must be designed and constructed to meet the basic requirements (Construction..., 2011). Water supply and sewer construction products made of steel, cast iron, plastic, etc. the technical specifications of materials (standards, technical approvals) must include:

- dimensional deviations;

- resistance to internal pressure;

- resistance to external pressure;

- resistance to external bending;

- durability with respect to length variation;

- longevity, taking into account the above-mentioned properties, and the operation of substances present in the soil or transferred to it in various ways.

Water supply pipes and other equipment which come into contact with water must be made of such materials as to prevent the release of substances harmful to health into the water and to prevent the growth of micro-organisms in the water supply and to impart any odour or taste to the water.

The requirements for a sewer are expressed in terms of the following requirements (technical parameters, their numerical values or other form), ensuring protection against:

- from the spread of odours;

- the risk of connection between the sewage and the water supply;

Copyright (C) 2021 The Authors. Published by Vytautas Magnus University. This is an open-access article distributed under the terms of the Creative Commons Attribution License (CC BY 4.0), which permits unrestricted use, distribution, and reproduction in any medium, provided the original author and source are credited. 
- $\quad$ runoff from sewage (microbiological pollution);

- $\quad$ entry of groundwater into sewer wells.

According to requirement "Sustainable use of natural resources" it is necessary that water and sewage networks must be designed, built and demolished in such a way to ensure:

- re-use or recyclability of structures, their materials and parts after demolition;

- durability of structures;

- the use of environmentally sound raw materials and secondary raw materials for construction. Long-lasting construction products must be used for installation.

\section{TEST METHODS}

Evaluating the indexes of manufacture and exploitation of external water supply and wastewater pipelines the data about different pipe types (concrete, reinforced concrete (RC), steel, cast iron, ceramic, polyvinylchloride (PVC), polyethylene (PE), polypropylene (PP), glass reinforced plastic (GRP)) properties and cost were analyzed.

For multi-criteria analysis data were gathered from the scientific studies (Rohrwerkstoffauswahl ..., 2005, 2006, 2009), technical data sheets and economic calculations. Eleven criteria were selected for the evaluation: variety of diameters, mass, resistance of lifting, thermal resistance, abrasion resistance, surface roughness (hydraulic property), nominal stiffness, nominal pressure, embodied energy, $\mathrm{CO}_{2}$ emission, and cost (product + installation). All criteria were evaluated on a 10 points system: 10 - excellent, 1 - very poor. The middle points were calculated according to proportion.

Two important criteria: lifetime and leakproof were not evaluated in this research. The lifetime of pipes is not evaluated due to lack of date of some of materials. In the second case nowadays all external water supply and wastewater pipelines must pass leakproof requirements. To reach this requirement all pipeline elements are connecting through rubber ring joints or with welding. The quality of pipeline installation is tested for leakage to ensure that any remaining defects are insignificant enough to allow operation at design pressures.

The main factor for the material selection is cost. Cost is the main criterion in public procurement. Therefore, the municipalities are constrained to choose the least expensive variants (with the least expensive materials). To evaluate these criteria an economic calculation for construction was done using the SES 2004 software. During the calculations the construction cost of $100 \mathrm{~m}$ length and $400 \mathrm{~mm}$ diameter pipe installation was estimated including all taxes valid in Lithuania.

\section{TEST RESULTS}

The widest selection of nominal diameter (DN) it is possible to find in PE pipes catalogues. The range of these pipes is from 15 to $3000 \mathrm{~mm}$ and the quantity of different DN is 53 . The second and third place in this category gets GRP and Steel pipes. They have 45 (range 150-3600 mm) and 33 (range $15-1200 \mathrm{~mm}$ ) different DN respectively. In the last place are non-reinforced concrete pipes with 11 different DN (range $250-900 \mathrm{~mm}$ ). The distribution of points is shown in Fig. 1.

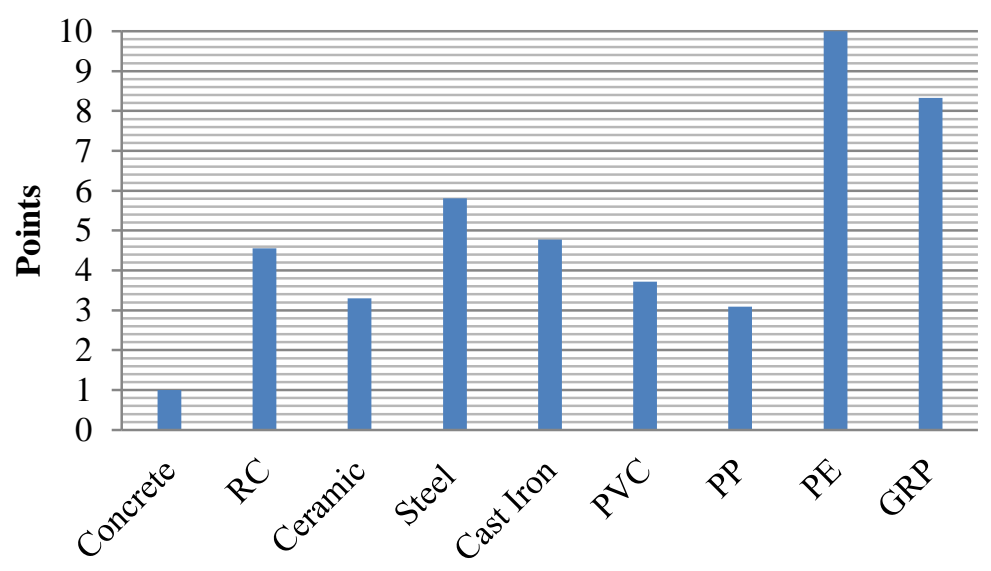

Figure 1. Points distribution according to variety of diameters

Two indexes were obtained from the mass of a $1 \mathrm{~m}$ long, $400 \mathrm{~mm}$ diameter pipe: resistance to lifting under hydrostatic pressure (the higher mass, will have the higher the resistance) and the difficulty of work, the effect of lifting mechanisms (the higher weight will have the higher working). The most resistant to lifting are reinforced concrete (10 points), the least resistant - GRP pipes (1 point) (Fig. 2), but the difficulty of the work is assessed in the opposite way: reinforced concrete pipes 1 point, GRP - 10 points (Fig. 3). 


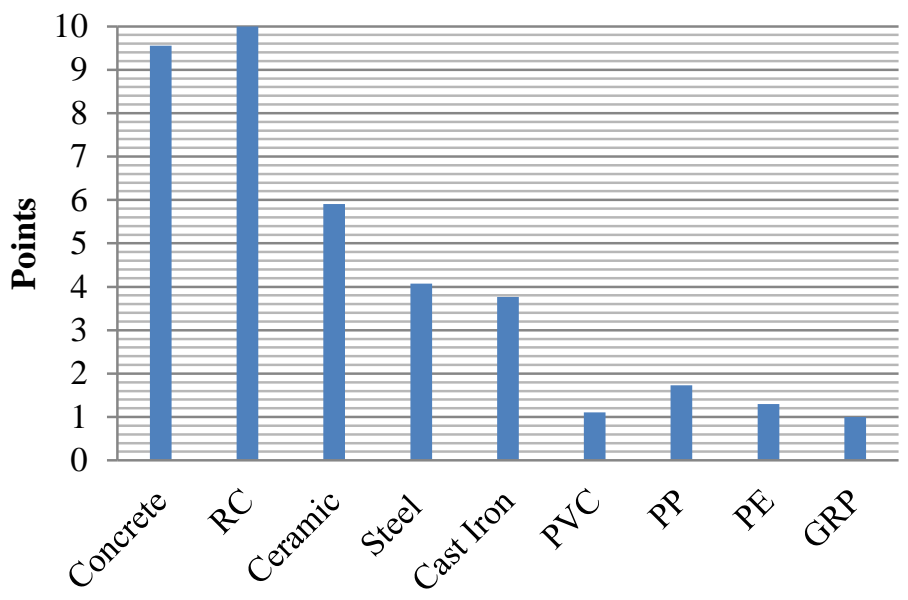

Figure 2. Points distribution according to resistant to lifting

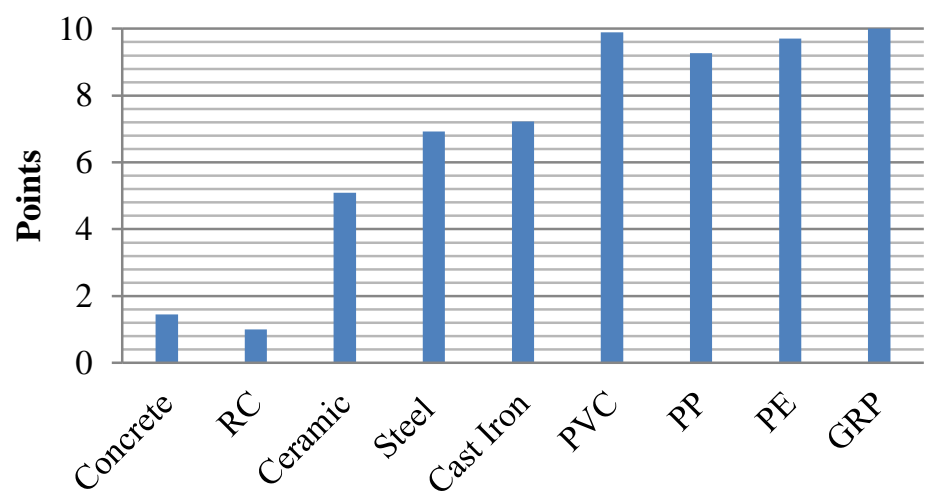

Figure 3. Points distribution according to difficulty of the work

The results show that when assessing the relative abrasion resistance, the highest scores are given to ceramic, concrete and reinforced concrete, the lowest - glass reinforced plastic (Fig. 4); the highest temperature deformations are characterized by polypropylene, polyethylene (assessed with 1 point), the smallest - ceramic (10 points), glass reinforced plastic, concrete, reinforced concrete, steel, cast iron (Fig. 5). Cast iron (10 points) is released at the highest nominal pressure, concrete and ceramic pipes at the lowest (Fig. 6). The hydraulic properties of the pipes are described in terms of equivalent roughness as follows: plastic pipes with the smoothest surface and the lowest equivalent roughness (10 points), concrete and reinforced concrete pipes with the highest equivalent roughness (1 point) (Fig. 7). Assessing the energy consumption (Fig. 8) and $\mathrm{CO}_{2}$ emissions (Fig. 9) required for the production of $1 \mathrm{~m}$ length and $400 \mathrm{~mm}$ diameter pipe, similar results were obtained: the production of concrete pipes has the lowest energy consumption and $\mathrm{CO}_{2}$ emissions (10 points), the highest - polypropylene and steel pipes. The highest strength and depth of installing are cast iron pipes (10 points), the lowest - PVC, PVC (1 point), PP and PE pipes (Fig. 10). Ceramic pipes (1 point) have the highest costs (production + installation) and PE pipes have the lowest (Fig. 11).

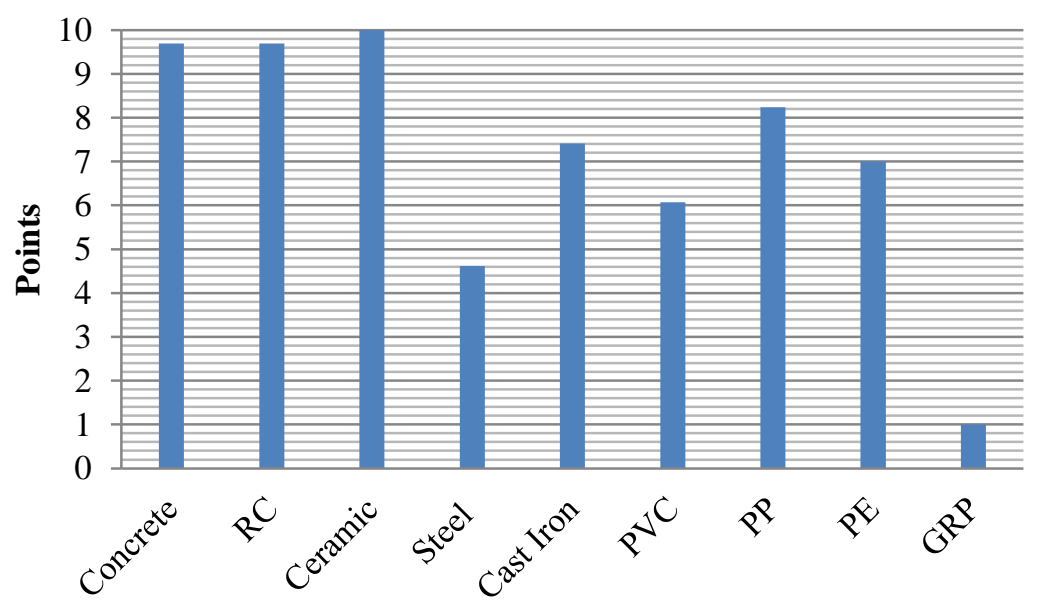

Figure 4. Points distribution according to abrasion resistance 


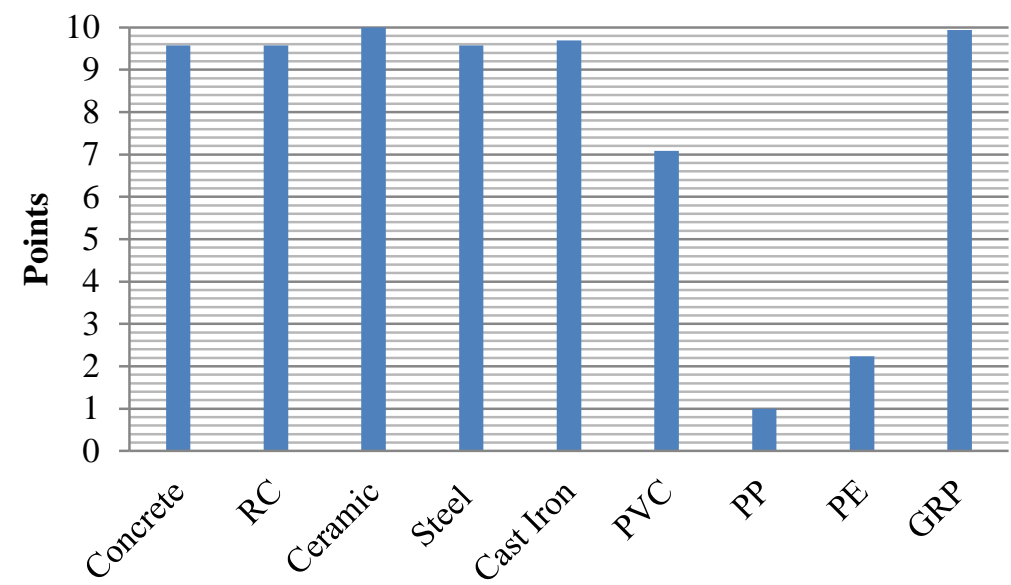

Figure 5. Points distribution according to thermal resistance

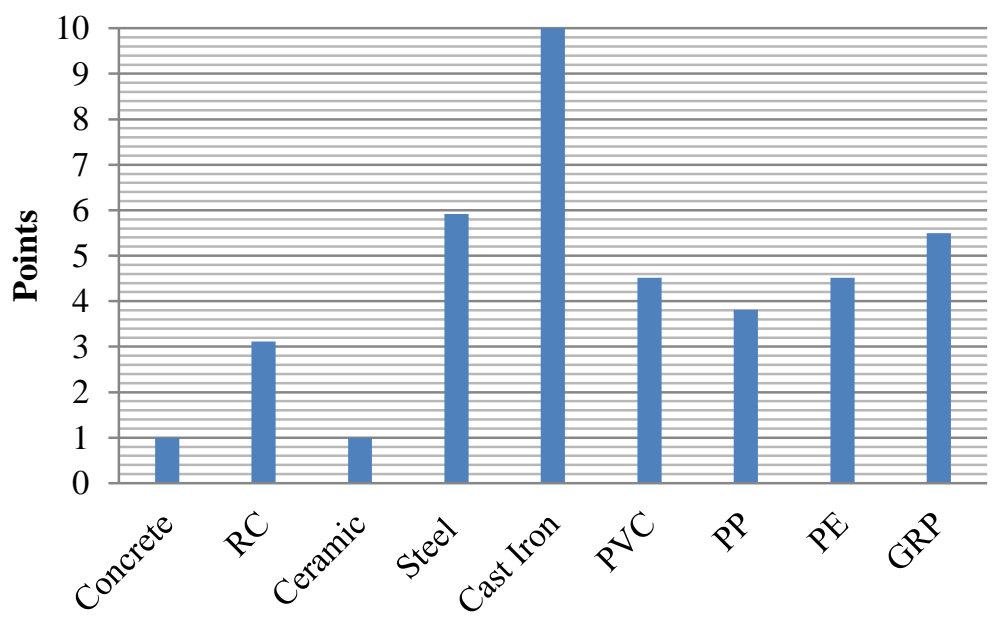

Figure 6. Points distribution according to nominal pressure (PN)

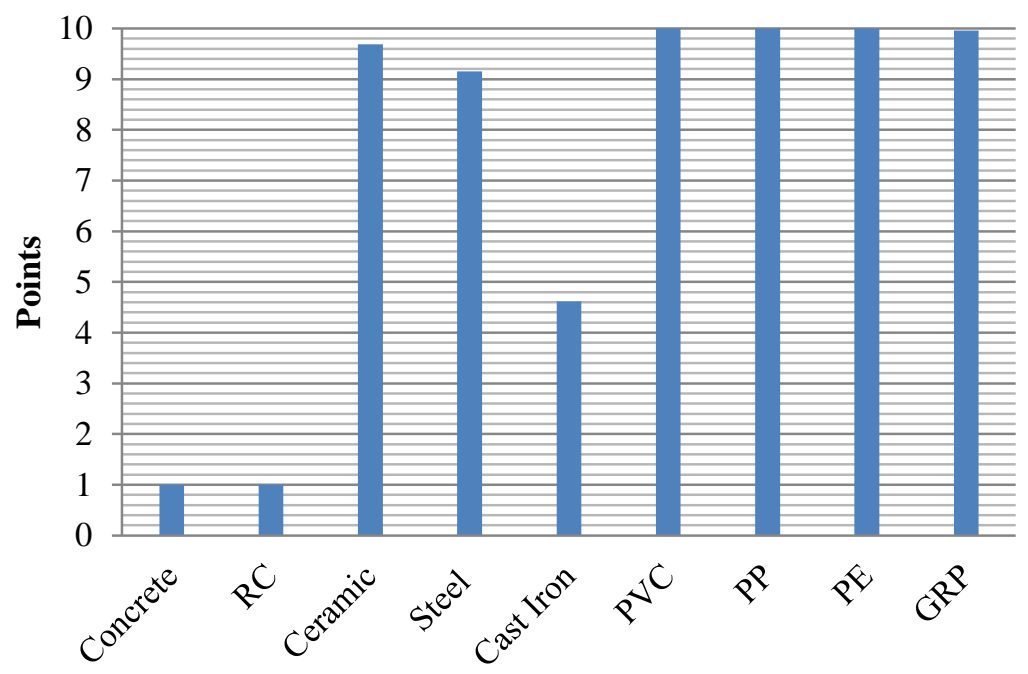

Figure 7. Points distribution according to surface roughness 


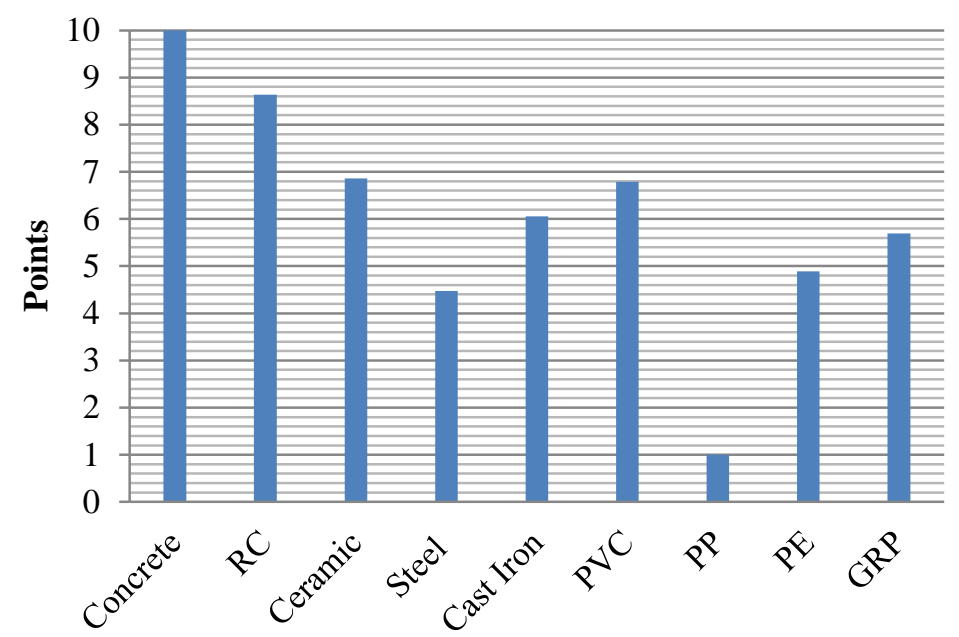

Figure 8. Points distribution according to embodied energy

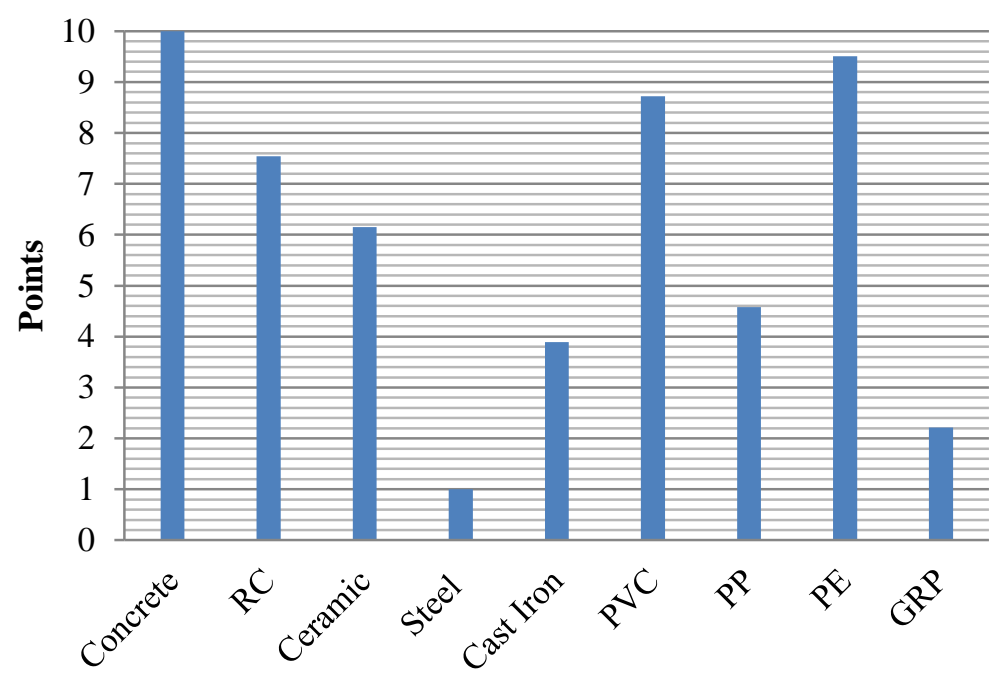

Figure 9. Points distribution according to $\mathrm{CO}_{2}$ emission

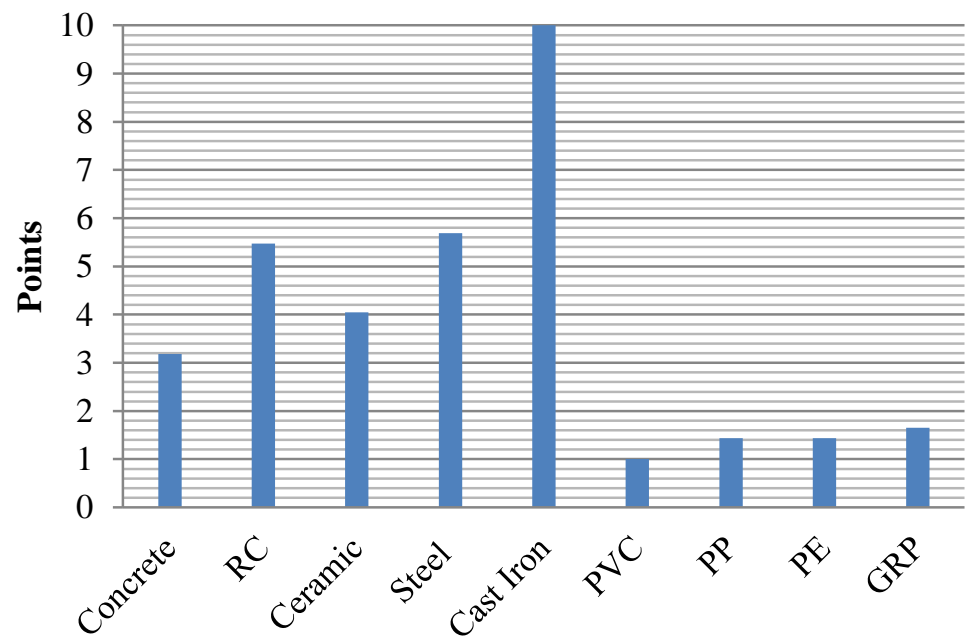

Figure 10. Points distribution according to nominal stiffness (SN) 


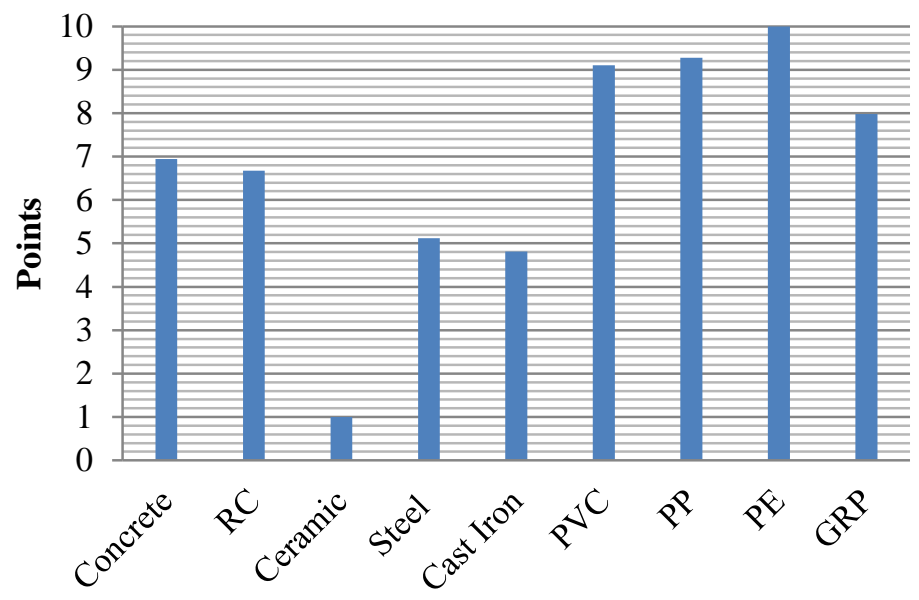

Figure 11. Points distribution according to cost (production + installation)

Summarizing all results were evaluated two variants:

- all criteria has the same weight;

- $\quad$ main criteria - cost (30\% weight).

According to the results (Fig. 12 and 13) in both cases the most effective material for pipes used in water supply and sewerage systems is PE and PVC. The last place take PP (where all criteria has same weight) and ceramic (with main criteria - cost) pipes.

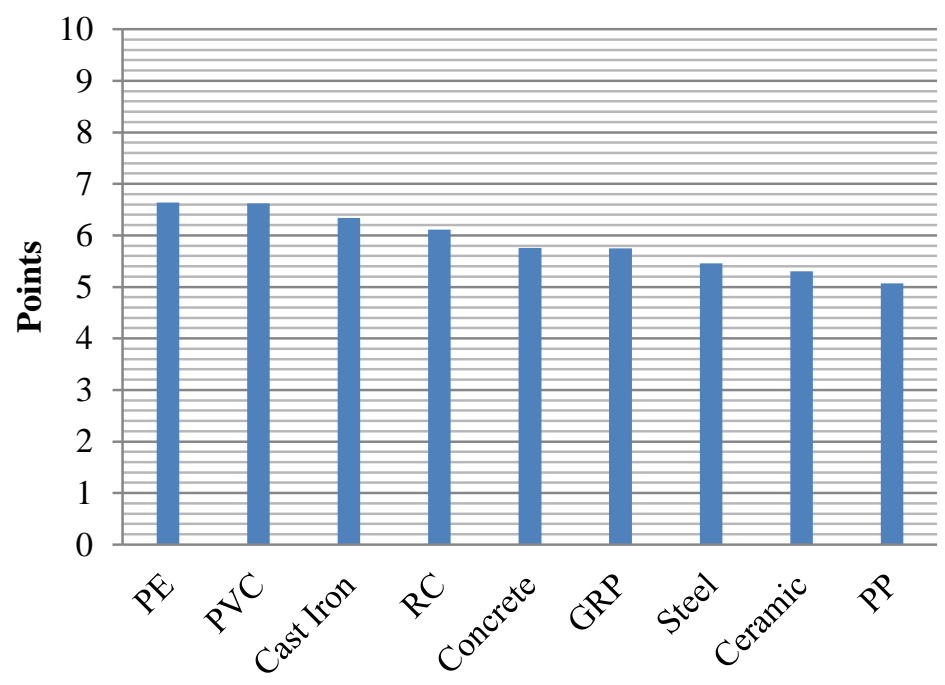

Fiure 12. The pipe material effectiveness (all criteria have the same weight)

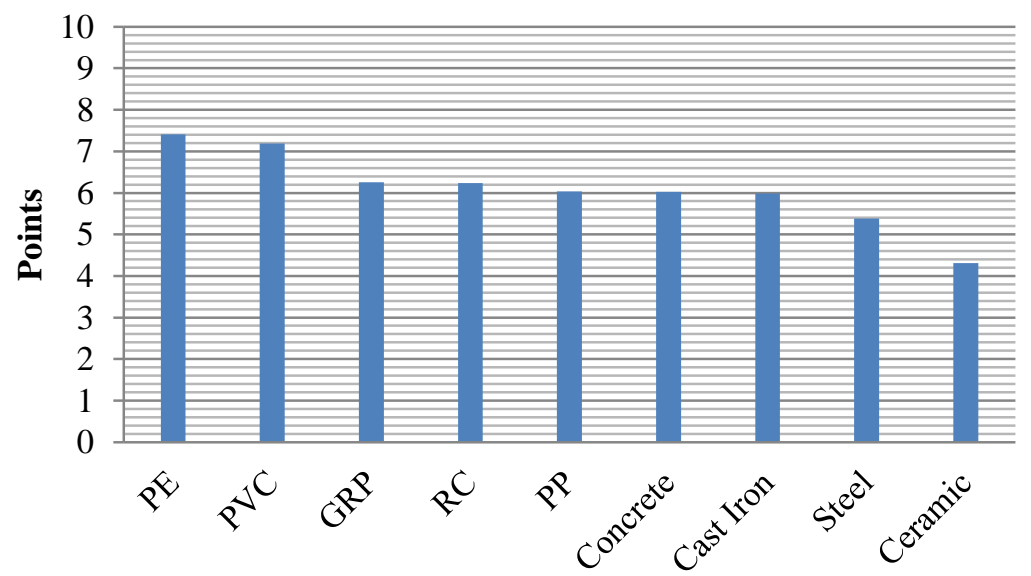

Figure 13. The pipe material effectiveness (main criteria - cost) 


\section{CONCLUSIONS}

Evaluating the pipes used for water supply and sewerage networks according to data the pipes are arranged in the following order of efficiency: Polyethylene (PE), Polyvinylchloride (PVC), Cast Iron, Reinforced concrete, Concrete, Glass reinforced plastic (GRP), Steel, Ceramic and Polypropylene (PP).

Evaluating the pipes used for water supply and sewerage networks with main criteria - cost, the pipes are arranged in the following order of efficiency: Polyethylene (PE), Polyvinylchloride (PVC), Glass reinforced plastic (GRP), Reinforced concrete, Polypropylene (PP), Concrete, Cast Iron, Steel and Ceramic.

\section{REFERENCES}

1. Abdallah M., Shanableh A., Elshazly D., Feroz S. 2020. Techno-economic and environmental assessment of wastewater management systems: Life cycle approach. Environmental Impact Assessment Review, Vol. 82, ID 106378. https://doi.org/10.1016/j.eiar.2020.106378

2. Construction Products Regulation (CRP) No. 305/2011.

3. Dennison F. J., Azapagic A, Clift R., Colbourne J. S. 1999. Life cycle assessment: comparing strategic options for the mains infrastructure - Part I. Water Science and Technology, Vol. 39, pp. 315-319. https://doi.org/10.2166/wst.1999.0673

4. Goraj W., Pytlak A., Kowalska B., Kowalski D., Grządziel J., Szafranek-Nakonieczna A., Gałązka A., Stępniewska Z., Stępniewski W. 2021. Influence of pipe material on biofilm microbial communities found in drinking water supply system. Environmental Research, Vol. 196. https://doi.org/10.1016/j.envres.2020.110433

5. Rohrwerkstoffauswahl - ein Vergleich. 2005. Abriebfestigkeit von Abwasserkanalrohren.

6. Rohrwerkstoffauswahl - ein Vergleich. 2005. Thermisches Verhalten von Abwasserkanalrohren.

7. Rohrwerkstoffauswahl - ein Vergleich. 2005. Verhalten von Abwasserkanalrohren bei Hochdruckspülung.

8. Rohrwerkstoffauswahl - ein Vergleich. 2006. Statische Tragfähigkeit und Verformungs-verhalten von Abwasserkanalrohren.

9. Rohrwerkstoffauswahl - ein Vergleich. 2006. Umweltvorträglichkeit/Ökobalanz von Abwasserkanalrohren.

10. Rohrwerkstoffauswahl - ein Vergleich. 2009. Dichtheit fur Entwasserrohren.

11. Vahidi E., Jin E., Das M., Singh M., Zhao F. 2015. Comparative Life Cycle Analysis of Materials in Wastewater Piping Systems. Procedia Engineering, Vol. 118, pp. 1177 - 1188. https://doi.org/10.1016/j.proeng.2015.08.461

12. Vahidi E., Jin E., Das M., Singh M., Zhao F. 2016. Environmental life cycle analysis of pipe materials for sewer systems. Sustainable Cities and Society, Vol. 27, pp. 167-174. https://doi.org/10.1016/j.scs.2016.06.028

13. Xiong J., Zhu J., He Y., Ren S., Huang W., Lu F. 2021. The application of life cycle assessment for the optimization of pipematerials of building water supply and drainage system. Sustainable Cities and Society, Vol. 60. ID 102267. https://doi.org/10.1016/j.scs.2020.102267 